\title{
Self-reported barriers and facilitators to preventive human papilloma virus vaccination among adolescent girls and young women: A systematic review
}

\author{
Lisa Rambout, Mariam Tashkandi, Laura Hopkins, and Andrea C. \\ Tricco
}

Version Post-print/Accepted Manuscript

\begin{abstract}
Citation ambout Lisa, Tashkandi Mariam, Hopkins Laura, Tricco Andrea C., (published version) Self-reported barriers and facilitators to preventive human papilloma virus vaccination among adolescent girls and young women: A systematic review, Preventive Medicine(2013), doi: 10.1016/j.ypmed.2013.10.009.

Copyright/License

(c) (1) $\odot$ This work is licensed under the Creative Commons BY NC ND Attribution-NonCommercial-NoDerivatives 4.0 International License. To view a copy of this license, visit http://creativecommons.org/licenses/by-nc-nd/4.0/.
\end{abstract}

How to cite TSpace items

Always cite the published version, so the author(s) will receive recognition through services that track citation counts, e.g. Scopus. If you need to cite the page number of the author manuscript from TSpace because you cannot access the published version, then cite the TSpace version in addition to the published version using the permanent URI (handle) found on the record page.

This article was made openly accessible by $U$ of $T$ Faculty. Please tell us how this access benefits you. Your story matters. 


\section{Accepted Manuscript}

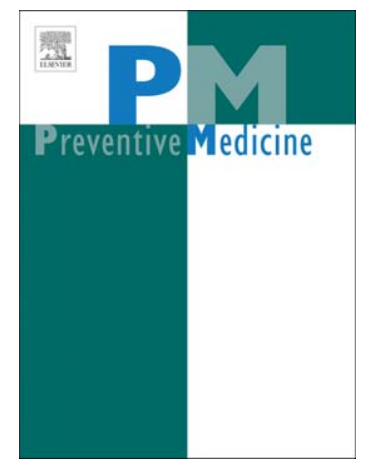

PII:

S0091-7435(13)00397-6

Reference: $\quad$ YPMED 3765

To appear in: $\quad$ Preventive Medicine

Please cite this article as: Rambout Lisa, Tashkandi Mariam, Hopkins Laura, Tricco Andrea C., Self-reported barriers and facilitators to preventive human papillomavirus vaccination among adolescent girls and young women: A systematic review, Preventive Medicine (2013), doi: 10.1016/j.ypmed.2013.10.009

This is a PDF file of an unedited manuscript that has been accepted for publication. As a service to our customers we are providing this early version of the manuscript. The manuscript will undergo copyediting, typesetting, and review of the resulting proof before it is published in its final form. Please note that during the production process errors may be discovered which could affect the content, and all legal disclaimers that apply to the journal pertain. 


\section{Self-reported barriers and facilitators to preventive human papillomavirus vaccination among adolescent girls and young women: A systematic review}

Lisa Rambout $^{\mathrm{a}}$, Mariam Tashkandi ${ }^{\mathrm{b}}$, Laura Hopkins ${ }^{\mathrm{c}}$, Andrea C. Tricco ${ }^{\mathrm{d}}$

a Department of Pharmacy, The Ottawa Hospital, Ottawa, Ontario, K1H 8L6, Canada; lrambout@toh.on.ca;

${ }^{\mathrm{b}}$ Applied Health Research Centre of St. Michael's Hospital, Toronto, Ontario, M5B 1M8, Canada; TashkandiM@smh.ca;

c Division of Gynaecologic Oncology, The Ottawa Hospital, Ottawa, Ontario, K1H 8L6, Canada; mhopkins@fhs.csu.mcmaster.ca

${ }^{d}$ Li Ka Shing Knowledge Institute of St Michael's Hospital, Toronto, Ontario, M5B 1T8, Canada; TriccoA@smh.ca;

Correspondence to: Lisa Rambout, Pharmacy Department, The Ottawa Hospital, General Campus, 501 Smyth Road, Ottawa, ON, K1H 8L6, Canada; Email:

lrambout@ottawahospital.on.ca; Telephone: (613) 737-8899 ext 75261, Fax: (613)737-8891.

Sources of support: We did not receive any funding to conduct this systematic review. ACT is funded by a Canadian Institutes for Health Research/Drug Safety and Effectiveness Network New Investigator Award in Knowledge Synthesis.

Word count: 200 (abstract), 4222 (main text), 1 figure, 5 tables, 3 Appendices, 32 references.

Key words: human papillomavirus, HPV, HPV vaccination, adolescence, young women, barrier, facilitator, HPV vaccine acceptability, self-report, systematic review, HPV vaccine uptake 


\begin{abstract}
Objective: Widespread uptake of preventive HPV vaccination among target groups is an important public health goal. To evaluate barriers and facilitators to HPV vaccination, we conducted a systematic review of self-reported views of adolescent girls and young women.

Methods: Twenty-two studies including 8079 females aged 9-26 years in North America, published between 2008 and 2011 (representing studies conducted post vaccine availability) were included. Two reviewers performed all levels of screening and data abstraction in duplicate. We collated findings pertaining to vaccination barriers and facilitators, study characteristics, and study quality.
\end{abstract}

Results: Participants were mainly unvaccinated (70\%) and sexually active. Twenty-one barriers to vaccination were identified. Cost was the most frequently reported barrier, followed by feelings that vaccination was unnecessary, and concerns regarding vaccine safety and side effects. Facilitators included perceived benefit of vaccination, health care provider recommendations, and social norms. Few studies specifically sought to isolate the views of adolescents, though not being sexually active was the most commonly reported barrier among this group.

Conclusion: Understanding factors which arbitrate in vaccination decisions among key target groups can improve the success of health promotion interventions. Additional studies of superior methodological quality are needed to produce reliable data to inform health promotion strategies. 


\section{Introduction}

Human papillomavirus (HPV) causes cancer, pre-cancerous and benign disease, and is widespread in the population. Three out of every four women will become infected with HPV, most commonly shortly after first sexual contact. (Baseman and Koutsky, 2005; Moore et al., 2009; Sellors et al., 2003). A preventive HPV vaccine against four strains of HPV became available in many countries in the world in 2006. Thereafter, the National Advisory Committee on Immunization in Canada (NACI) and the Advisory Committee on Immunization Practices (ACIP) in the United States issued recommendations to advise that adolescent girls should receive the vaccine, prior to sexual debut, in order to prevent HPV-associated disease (Markowitz et al., 2007; National Advisory Committee on Immunization, 2007).

Notwithstanding these recommendations, HPV vaccine uptake has been poor in most jurisdictions in Canada and the United States even when available through publicly-funded programs. Though embedded in a complex social dynamic, the perspective of adolescent girls is an essential component of determining factors which have both prompted and precluded HPV vaccination. Academic reaction to vaccine controversy spawned a deluge of studies examining HPV vaccine acceptability among various groups. These studies have revealed a broad range of concerns including vaccine effectiveness, vaccine safety, and perceived disease risk (Brewer and Fazekas, 2007). To date, however, the vast majority of research has examined issues related to HPV vaccine acceptability from the perspective of parents, care providers, and policymakers. Literature examining vaccine acceptability from the viewpoint of intended recipients is lacking, particularly with respect to adolescents.

Identifying barriers and facilitators to HPV vaccination from the adolescent perspective is important. For public health, reducing HPV-associated disease burden in the population depends upon universal uptake among target adolescent groups (Heffernan et al., 2010; Kane, 2010; Sneller et al., 2008). For health policy, information may be obtained regarding optimal health promotion strategies which are accurately focused on gaps, ensure wise use of health care dollars, and have the greatest potential to translate into positive health outcomes. And, for 
adolescents, it aims to acknowledge and address their needs more specifically which may, in turn, cultivate healthy behaviours commencing at an early and impressionable age.

Our objective was to systematically review the literature in order to draw together, summarize, and critically appraise the body of evidence that has examined self-reported barriers and facilitators to preventive HPV vaccination from the viewpoint of adolescent girls and young women in Canada and the United States.

\section{Methods}

\section{Protocol}

This systematic review was conducted as part of a MSc thesis by the first author. A systematic review protocol was compiled and reviewed by clinical and methodological experts. It is available from the first author upon request.

\section{Eligibility criteria}

Quantitative and qualitative studies examining self-reported barriers and facilitators to preventive HPV vaccination conducted among adolescent girls and young women (aged 9 to 26 years) were included. This age range was chosen because it encompasses the currently targeted population. Only studies conducted in Canada and the United States were included to obviate differences in culture, religion, population demographics, messaging in the media, and other nation-specific factors from different areas of the world. Studies written in English and conducted after June 2006 (to correspond with the date of licensure of the first available prophylactic HPV vaccine) were included. Only studies of self-reported barriers and facilitators were sought; those which identified correlations inferred from statistical associations with demographic features were excluded. Studies involving both vaccinated and unvaccinated participants were eligible.

\section{Outcome measures}

\section{Primary outcome:}


The primary outcome of the review was self-reported barriers and facilitators to preventive HPV vaccination among females 9-26 years of age. For quantitative analyses, this included barriers and facilitators found to be statistically significantly associated with vaccination intention or uptake, those identified as proportions of participants reporting a particular barrier or facilitator, or ranking of reported barriers and/or facilitators. For qualitative data, this included all barriers and facilitators reported by study participants. A barrier was defined as any factor reported by an intended vaccine recipient as being negatively associated with the likelihood of vaccination or vaccine uptake. Conversely, a facilitator was defined as a factor positively associated with vaccination likelihood or uptake.

\section{Secondary outcome:}

We also sought to explicitly determine what is known about barriers and facilitators to HPV vaccination from the perspective of adolescents, which is generally defined as the period commencing with puberty and ending when age 18 or 19 years is reached. As such, self-reported barriers and facilitators specifically reported by girls within the age range of 9-17 years formed the secondary outcome for the review. Examining this age group separately also more closely approximates one of the distinct target groups for preventive vaccination against HPV: 11-12 year old females in the United States, as recommended by ACIP; and 9-13 year old females in Canada, as recommended by NACI. Beyond these ages, catch-up vaccination is recommended by both advisory committees up to age 26 (Markowitz et al., 2007; National Advisory Committee on Immunization, 2007).

For studies which collected self-reported information and then analyzed the data for associations with vaccination intent or uptake, only correlations with attitudes or vaccination perceptions were considered. Outcomes based upon associations with demographics, behaviours, and HPV or HPV vaccine knowledge was excluded. The inclusion and exclusion criteria for the review are summarized in Appendix A.

\section{Information sources and search}

Electronic literature searches were conducted in MEDLINE, including In-Process and Other Non-Indexed Citations (1948 to April week 1 2011), EMBASE (1947 to 2011 April 13), 
CINAHL, and PsycINFO (2002 to April, week 1, 2011). All search strategies were developed and executed by an experienced information specialist using relevant medical subject headings (or MeSH terms) and free-text terms identified from other reviews on HPV vaccine acceptability. The fully developed electronic search strategy for the Medline and EMBASE databases are presented in Appendix B. All other searches were customized for each database separately. The search was limited to the year 2006 onwards and to studies written in English. The electronic search was supplemented by searching the ProQuest Theses and Dissertations database, scanning the reference lists of included studies, and scanning the references of selected narrative reviews published in 2010 and 2011.

\section{Study selection}

Two reviewers performed all levels of screening in duplicate and reasons for exclusion were documented. Discrepancies were resolved by consensus or the involvement of a third reviewer. Study authors were contacted in several instances to determine eligibility for the review.

\section{Data collection and data items}

A data abstraction form was developed a priori and pilot-tested by two reviewers. Two reviewers then performed all data abstraction in duplicate. Authors were contacted regarding missing information, as necessary.

Data abstracted from each report included demographic characteristics pertaining to the participants in the study (e.g. age, ethnicity, relationship status, sexual history, education level), the study setting (e.g. country, university versus medical clinic), study details (study type, funding sources, sampling and data collection methods, theoretical framework), and the outcomes assessed (i.e. barriers and facilitators to vaccination). Study conclusions were also abstracted.

\section{Methodological quality}


The methodological quality of included studies was assessed using a 16-item scale developed and evaluated for appraising studies with diverse designs (Sirriyeh et al., 2012). The tool, based upon a 4-point scoring system for each item, permitted assessment of the overall quality of mixed qualitative and quantitative evidence using a unified set of criteria. Additional quality assessments were conducted to appraise the reliability and validity of the data pertaining to important outcomes reported in each of the studies. This involved evaluating the studyimposed limitations on self-reports of barriers and facilitators by respondents and correlation of outcomes with vaccination interest, acceptability, or intent versus actual uptake in each of the studies. Quality scoring and assessments were performed independently by two reviewers. Discrepancies were resolved through an iterative consensus approach and by consulting a methodologist when required.

\section{Data synthesis}

Descriptive synthesis of abstracted data was completed for all included studies with respect to study characteristics, study outcome results, and study quality. Heterogeneity among studies precluded meta-analysis.

\section{Results}

Literature search

A total of 1308 records were identified from the literature and screened (Figure). Of these, 123 potentially relevant full-text reports were obtained and reviewed, yielding 22 unique studies which met the inclusion criteria for the review: 19 of these were published articles, 1 was a report of data which otherwise met the inclusion criteria, and two were thesis dissertations. At the full-text level of screening, 97 articles were excluded because they did not examine vaccine acceptability among females aged 9-26 years $(n=34)$, were not conducted in the US or Canada $(\mathrm{n}=18)$, did not provide relevant data $(\mathrm{n}=21)$, were conducted prior to the availability of the vaccine $(n=15)$, and did not provide original data $(n=9)$.

\section{Study characteristics}


Of the 22 unique studies, 21 were conducted in the United States, and one was conducted in Canada (Table 1). Nineteen were quantitative studies, one was a qualitative study, and two used mixed qualitative/quantitative methods. Twenty of the studies used questionnaires that were conducted in either paper format, over the telephone, or electronically and two studies used indepth interviews conducted with each study participant individually. The earliest study began recruiting participants in October 2006 and the most recent study completed enrolment in the fall of 2009. Most of the studies $(n=14)$ were designed to address multiple objectives in addition to addressing barriers and facilitators to vaccine uptake; such as knowledge, awareness, rates of uptake, sexual behaviour, education, and HPV prevalence. Nine of the studies were conducted in educational settings, eight were conducted in locations related to the provision of health care services, and in five studies participants were selected from among the general population.

Among the 22 studies, a total of 8079 adolescent girls and young women age 26 years or younger from diverse groups contributed their views (based upon the 21 studies that reported a sample number). In three cases, the studies also enrolled older women; however, outcome data were reported separately for participants 26 years of age or younger and thus satisfied our inclusion criteria for the review. Twelve studies involved mainly White participants and in five studies participants were primarily Black. Hispanics comprised the next most common race represented among studies. Collectively, from those studies which reported vaccination status (19), approximately $70 \%$ of the population of adolescent girls and young women were unvaccinated and $30 \%$ had received at least one dose of an HPV vaccine. Almost all participants were aware of HPV or the HPV vaccine, but this was only reported in nine of the studies. Based upon nine reports, more than half of the girls and young women were sexually active, except in one case where $71 \%$ of participants at a religiously conservative Lutheran university had never had vaginal intercourse. Some of the participants reported having a prior sexually transmitted infection, abnormal Pap smear tests, or prior HPV infection but this information was reported in few of the included studies.

\section{Primary Outcome (adolescent girls and young women age 9-26 years)}

A total of 21 barriers were reported among studies for the combined 9-26 year age range, seven were identified as statistically significant results from quantitative studies; 18 were 
reported as proportions in quantitative studies; and 12 were identified from three qualitative investigations (Table 2). Cost was reported as a barrier in the highest number of studies $(n=10)$. Feeling that the vaccine was not needed for various reasons, and concerns related to vaccine safety and potential side effects were the next most commonly reported barriers; each was reported in nine of the studies. Of the 11 different facilitators reported among studies, eight were identified as statistically significant results, seven as proportions from quantitative studies, and six from qualitative investigation. The most commonly reported facilitators were perceived benefit of the vaccine and receiving a recommendation from a health care provider, which were each reported in six of the studies. Social norms were the next most commonly reported facilitator, which was reported in five of the studies.

\section{Secondary outcome (adolescent girls age 9-17 years)}

From the three studies reporting results specifically for adolescent girls under the age of 18 years, 706 adolescent girls are represented (Table 3). A total of ten barriers and six facilitators were reported. All were reported from quantitative studies which reported proportions of girls who identified each barrier or facilitator to vaccination. Not being sexually active was the barrier reported by the highest proportion of girls ( $47 \%$ in the one study which identified this barrier). This was followed by a feeling of not being at risk, which was reported by $36 \%$ of girls in a different study. Two of the studies reported concerns about vaccine safety as a barrier (reported by $26 \%$ and $25 \%$ of adolescent girls in each of the studies, respectively).

\section{Methodological quality}

Twenty-one of the 22 included studies were evaluated for quality (Table 4 \& Table 5), as one study only reported their results and not their methods. Among the evaluated studies, seven reported the application of a specific theoretical framework or constructs upon which to base their investigation. Eleven of the studies completely identified their objectives, and research setting. None of the studies were judged to have used a sample that was broadly representative of the target population. However, many were designed to address a specific subgroup of the target population, such as racially and ethnically diverse groups of adolescent girls and young women. The procedures used in collecting data were described in detail in 12 of the studies. However, the rationalization for the choice of data collection tools and the fit of the data collection method 
with the stated research questions were judged as slight or moderate in almost all studies. The content of the data collection instruments was highly investigator driven in most instances and questioning primarily involved fixed responses and closed-ended questioning. Specific questions asked in the studies were only provided in seven of the reports. Three other reports provided some information about the questions used and two studies mentioned that the information was available from the authors upon request.

Among the studies there was not a great deal of evidence to suggest that investigators had attempted to assess the reliability and validity of the measurement tools used. Some of the studies mentioned that these assessments had been made in prior studies but details were not provided. None of the studies provided a complete justification for the choice of analytical methods in the context of the study's stated research questions. The fit between the analytical methods and study research questions was judged as moderate in most cases. There was some evidence of user involvement in the design of nine of the studies but this usually entailed the involvement of other experts in the field as opposed to the end users of the research who might be able to apply the results, such as public health personnel and policy-makers; the involvement of adolescent girls and young women themselves was uncommon. In some cases authors mentioned cognitive and field testing of data collection instruments but the population used for these assessments was not always clear.

\section{Discussion}

From the combined evidence for females from the ages of 9-26, participant self-reports revealed 22 barriers to HPV vaccination. Cost was most commonly identified and our findings indicate that when cost is a factor in vaccine access, it dominates as a barrier. This lends support to the implementation of publicly-funded vaccination programs for target groups. Still, it is important to also consider that cost concerns may be inflated by a lack of perceived value in receiving preventive HPV vaccination. In fact, feelings of not needing the vaccine predominated as the second most common barrier to vaccination. Young women frequently viewed themselves as not at risk of acquiring HPV or that the severity of HPV infection did not warrant vaccination. In particular, it seemed that young women tended to consider their present circumstances with respect to sexual activity and relationship status when contemplating vaccination. Sexually 
inactive females tended to be less convinced by risk concerns compared to populations comprised of more sexually active young women, some with a history of sexually transmitted infections, who tended to accept vaccination due to a perception that they were at risk for HPV. This suggests that, young women need to perceive themselves at risk in order to view vaccination as personally valuable. Furthermore, educational initiatives should aim to improve awareness of HPV transmission and its associated health consequences, including pre-cancerous disease significance.

Our results also indicate that concerns about safety and side effects are deterrents to HPV vaccine uptake among young women. This again suggests that education is necessary for this target population, to reassure them that the vaccine is safe and that serious side effects are rare. Practical barriers were also revealed as an important obstacle to vaccination, such as the need to make health care appointments, arrange transportation, and remember to get all three vaccine doses; issues rarely exposed by earlier studies that used hypothetical 'intention to vaccinate' outcomes. Many of these factors appeared to be particularly relevant among ethnically diverse and low income populations. Barriers related to lack of knowledge and awareness about HPV, though less common as vaccination becomes more widespread, continue to exist and do arbitrate as important barriers when present.

Of the 11 facilitators of vaccination identified in our review, perceived benefit and health care provider recommendation were most commonly identified. Data related to the perceived benefits of vaccination came mostly from studies conducted among private school and university students. In other, more diverse populations, girls and young women tended to frame their attitudes toward vaccination mainly from personal experiences, such as an abnormal Pap test result, rather than from a perception of future or hypothetical benefits. One study in our review found that young women consider the cancer benefits of vaccination more important than antiwarts benefits (Watts et al., 2009).

Also evident from our findings is the important role health care providers play in the delivery of HPV vaccine messages. Yet while health care provider recommendations are of consistently identified importance in studies which examine this subject, their relative importance is not well understood as they have not typically been examined in the context of 
other potential barriers and facilitators. It is also notable that health care provider influences can be both positive and negative. Doctor-related barriers such as missed opportunities to discuss vaccination, poor communication, and discouragement of vaccination were also identified in our review. One study revealed that health care provider messages are often not delivered in a way that is clearly and easily understood by young women (Bynum et al., 2009).

In order to gain a deeper understanding of aspects central to vaccination decisions among adolescents, the evidence compiled in our review was further distilled to yield a subset of 706, 917 year old girls from three studies. Among these adolescents, not believing there was a need for vaccination, either because of sexual inactivity or not believing they were at risk, formed the predominant obstacle to vaccination. Adolescent girls were most encouraged to seek vaccination if they received parental or health care provider endorsement. Furthermore, our findings reveal additional issues that may be primarily relevant to a younger population, such as fear of needles and social norms. Of note, our review did not find any qualitative studies conducted among adolescent girls aimed at eliciting their unprompted views.

A previously conducted systematic review by Brewer and Fazekas examined hypothetical HPV vaccine acceptability among adolescents, young adults, and parents. (Brewer and Fazekas, 2007). All studies were carried out prior to HPV vaccine availability. Their review identified perceived effectiveness of the vaccine and physician recommendations as key cues to action while barriers to acceptability included cost and the belief that vaccination would promote sexual activity. Despite some similarities with our findings, the validity of their findings is limited by the questionable relationship between vaccine acceptability and actual vaccine uptake, and also by the kaleidoscope of represented views with small numbers of adolescents. The concerns of adolescent girls are unique to their stage of life and warrant independent investigation. Although we limited our review to females 9-26 years of age, the tendency to merge populations of adolescents and adults in behavioural HPV research remained evident. Of the 22 included studies only three considered adolescents separately. Furthermore, we found that the number of studies that examined barriers and facilitators to HPV vaccination from the perspective of individuals other than adolescents themselves outnumbered adolescent studies by a factor of more than seven to one.

Taken altogether, our findings may have broad application to sectors such as public 
health and policy-makers in terms of program development and intervention design. Whereas targeted approaches to intervention design will rely on an understanding of the salient mediating factors, such guidance is as yet scant from currently available evidence. Tailored interventions may be an optimal choice for a complex health intervention such as preventive HPV vaccination and the data brought together in our review have potential to be used to design tailored interventions that are amenable to adaptation as new research findings become available. Almost all of the studies in our review recommended age appropriate educational initiatives.

\section{Study limitations and strengths}

To our knowledge, this is the first systematic review to isolate the views of adolescent girls and young women with respect to the acceptability of preventive HPV vaccination. Acceptability data is required to provide information about how vaccination uptake may be improved among target groups. This is of particular importance, as the uptake of the HPV vaccine has been low in Canada and the United States. Previous reviews of vaccine acceptability have not addressed actual vaccine uptake nor have they isolated the views of intended vaccine recipients. Most describe vaccine acceptability at a time prior to vaccine approval, which might not reflect the opinions of adolescents and women after vaccine availability. Furthermore, previous reviews merge the views of parents, health care providers, and others, making it difficult to tease out the perspective of the target vaccine population. Our review focuses on the views of adolescent girls and young women and consequently contributes valuable information regarding the group primarily targeted for vaccination and for whom the greatest benefit is derived.

Notwithstanding the importance of the perspective of young females, we acknowledge the indispensable role that parents, health care providers, and others play in prompting vaccination and encourage the results of our systematic review to be considered in context with evidence related to the views of these influential others. Taken together, the collective data may provide guidance for the development of health promotion programs concerning HPV vaccination. Incorporating the views of adolescent girls and young women targeted for vaccination increases the likelihood that such programs will be successful. 
There are several limitations in the included studies. From the evidence it is difficult to ascertain if the views of adolescents are truly reflected in the reported outcomes since the questioning in most instances was pre-established and to a large extent chosen by the investigators. There was very often no detail reported regarding questions asked or themes explored. More qualitative investigation is required to improve the breadth of our understanding of the salient issues. Only seven of the studies included in our review mentioned the application of a theoretical framework to underpin the research and even fewer justified their model selection or explained how the theory was used to inform the study design. The incomplete and suboptimal use of theory among studies limited our ability to ascribe superlative relevance to any one particular theory or construct to guide future research or program planning. In addition, most of the included studies had multiple aims and, in most cases, investigation of self-reported barriers and facilitators to vaccination decisions was not the primary outcome of interest. Often, only small subsets of the overall study population were the source of information about barriers and facilitators to vaccination among adolescent girls and young women. More studies specifically designed to address self-reported barriers and facilitators to HPV vaccination, particularly among adolescents, are necessary.

As we look to the future of preventive HPV vaccination we must consider that current initiatives to promote the vaccine among various catch-up populations will gradually dissipate, leaving us with an unchanging need to ensure vaccine uptake among adolescent girls. Our efforts will help young people transition into healthy adults who are not adversely impacted by numerous health-related consequences including those associated with HPV.

\section{Conclusion}

In our systematic review, we have aimed to place the viewpoint of the essential target group for preventive HPV vaccination at the centre of our inquiry into factors which arbitrate in their decisions. We have found that young women up to the age of 26 often feel that they do not need the HPV vaccine and that they view cost as an important barrier to vaccination. Safety and side effects are additional concerns. We found that young women are most encouraged to seek vaccination if they perceive a benefit to vaccination. And, while endorsement by influential others, such as parents and health care providers, appear to be important factors in prompting 
vaccination, communication can sometimes be suboptimal or unclear. Furthermore, we found that adolescent girls do not perceive a need to get vaccinated until becoming sexually active. They commonly fear needles, want more information about vaccine safety and efficacy, and do consider parental approval important. Our results should be interpreted with caution, due to the limitations identified in the included studies. 


\section{Acknowledgements}

We thank Risa Shorr, Library Services, The Ottawa Hospital, for her assistance with the search strategy and acquisition of articles. We also thank Jennifer D'Souza, research assistant of the Knowledge Translation Program at the Li Ka Shing Knowledge Institute of St. Michael's Hospital, for her assistance with the manuscript preparation and submission. ACT is funded by a Canadian Institutes for Health Research/Drug Safety and Effectiveness Network New Investigator Award in Knowledge Synthesis.

\section{Conflict of Interest Statement}

All authors have completed the Conflict of Interest Policy available on request from the corresponding author and declare that: (1) LR, MT, LH, \& ACT did not receive any financial support for the submitted work; (2) LR, MT, \& LH have no relationships with any companies that might have an interest in the submitted work in the previous 3 years, ACT was a consultant for GlaxoSmithKline Canada vaccine products, including their human papillomavirus vaccine from December 2003 until September 2011; (3) their spouses, partners, or children have no financial relationships that may be relevant to the submitted work; and (4) LR, MT, LH, \& ACT have no non-financial interests that may be relevant to the submitted work. 


\section{References}

Allen JD, Mohllajee AP, Shelton RC, Othus MK, Fontenot HB, Hanna R, 2009. Stage of adoption of the human papillomavirus vaccine among college women. Preventive medicine 48:420-5.

Baseman JG, Koutsky LA, 2005. The epidemiology of human papillomavirus infections. Journal of clinical virology : the official publication of the Pan American Society for Clinical Virology 32 Suppl 1:S16-24.

Bendik MK, Mayo RM, Parker VG, 2011. Knowledge, perceptions, and motivations related to HPV vaccination among college women. Journal of cancer education : the official journal of the American Association for Cancer Education 26:459-64.

Brewer NT, Fazekas KI, 2007. Predictors of HPV vaccine acceptability: a theory-informed, systematic review. Preventive medicine 45:107-14.

Bynum SA, Wright MS, Brandt HM, Burgis JT, Bacon JL, 2009. Knowledge, beliefs, and attitudes related to human papillomavirus infection and vaccination, pap tests, and cervical intraepithelial neoplasia among adolescent girls and young women. Journal of the South Carolina Medical Association 105:267-72.

Caskey R, Lindau ST, Alexander GC, 2009. Knowledge and early adoption of the HPV vaccine among girls and young women: results of a national survey. The Journal of adolescent health : official publication of the Society for Adolescent Medicine 45:453-62.

Conroy K, Rosenthal SL, Zimet GD, Jin Y, Bernstein DI, Glynn S, Kahn JA, 2009. Human papillomavirus vaccine uptake, predictors of vaccination, and self-reported barriers to vaccination. Journal of women's health 18:1679-86.

Costar H, 2008. Creating persuasive health messages: consideration of future consequences and intention to pursue vaccination against human papillomavirus. Dissertation Abstracts International: Section B: The Sciences and Engineering 69.

Dillard JP, Spear ME, 2011. Knowledge of human papillomavirus and perceived barriers to vaccination in a sample of US female college students. Journal of American college health : J of ACH 59:186-90.

Gerend MA, Magloire ZF, 2008. Awareness, knowledge, and beliefs about human papillomavirus in a racially diverse sample of young adults. The Journal of adolescent health : official publication of the Society for Adolescent Medicine 42:237-42. 
Grant D, Kravitz-Wirtz N, Breen N, Tiro JA, Tsui J, 2009. One in four California adolescent girls have had human papillomavirus vaccination. Policy brief:1-6.

Heffernan ME, Garland SM, Kane MA, 2010. Global reduction of cervical cancer with human papillomavirus vaccines: insights from the hepatitis B virus vaccine experience. Sexual health 7:383-90.

Hopfer S, Clippard JR, 2011. College women's HPV vaccine decision narratives. Qualitative health research 21:262-77.

Jain N, Euler GL, Shefer A, Lu P, Yankey D, Markowitz L, 2009. Human papillomavirus (HPV) awareness and vaccination initiation among women in the United States, National Immunization Survey-Adult 2007. Preventive medicine 48:426-31.

Janousek J, 2011. Knowledge, attitudes, beliefs, and predictors of acceptance of the human papillomavirus vaccination of college women at a Midwest Lutheran university: a quantitative study. Abstracts International: Section B: The Sciences and Engineering 71.

Kahn JA, Rosenthal SL, Jin Y, Huang B, Namakydoust A, Zimet GD, 2008. Rates of human papillomavirus vaccination, attitudes about vaccination, and human papillomavirus prevalence in young women. Obstetrics and gynecology 111:1103-10.

Kane MA, 2010. Global implementation of human papillomavirus (HPV) vaccine: lessons from hepatitis B vaccine. Gynecologic oncology 117:S32-5.

Lenehan JG, Leonard KC, Nandra S, Isaacs CR, Mathew A, Fisher WA, 2008. Women's knowledge, attitudes, and intentions concerning Human Papillomavirus vaccination: findings of a waiting room survey of obstetrics-gynaecology outpatients. Journal of obstetrics and gynaecology Canada $:$ JOGC = Journal d'obstetrique et gynecologie du Canada : JOGC 30:489-99.

Licht AS, Murphy JM, Hyland AJ, Fix BV, Hawk LW, Mahoney MC, 2010. Is use of the human papillomavirus vaccine among female college students related to human papillomavirus knowledge and risk perception? Sexually transmitted infections 86:74-8.

Markowitz LE, Dunne EF, Saraiya M, Lawson HW, Chesson H, Unger ER, Centers for Disease C, Prevention, Advisory Committee on Immunization P, 2007. Quadrivalent Human Papillomavirus Vaccine: Recommendations of the Advisory Committee on Immunization Practices (ACIP). MMWR. Recommendations and reports : Morbidity and mortality weekly report. Recommendations and reports / Centers for Disease Control 56:1-24. 
Mathur MB, Mathur VS, Reichling DB, 2010. Participation in the decision to become vaccinated against human papillomavirus by California high school girls and the predictors of vaccine status. Journal of pediatric health care: official publication of National Association of Pediatric Nurse Associates \& Practitioners 24:14-24.

Moore GR, Crosby RA, Young A, Charnigo R, 2010. Low rates of free human papillomavirus vaccine uptake among young women. Sexual health 7:287-90.

Moore RA, Ogilvie G, Fornika D, Moravan V, Brisson M, Amirabbasi-Beik M, Kollar A, Burgess T, Hsu R, et al., 2009. Prevalence and type distribution of human papillomavirus in 5,000 British Columbia women--implications for vaccination. Cancer causes \& control: CCC 20:1387-96.

National Advisory Committee on Immunization, 2007. Statement on human papillomavirus vaccine. An Advisory Committee Statement (ACS). Canada communicable disease report $=$ Releve des maladies transmissibles au Canada 33:1-31.

Rand CM, Schaffer SJ, Humiston SG, Albertin CS, Shone LP, Heintz EV, Blumkin AK, Stokley S, Szilagyi PG, 2011. Patient-provider communication and human papillomavirus vaccine acceptance. Clinical pediatrics 50:106-13.

Read DS, Joseph MA, Polishchuk V, Suss AL, 2010. Attitudes and perceptions of the HPV vaccine in Caribbean and African-American adolescent girls and their parents. Journal of pediatric and adolescent gynecology 23:242-5.

Rosenthal SL, Weiss TW, Zimet GD, Ma L, Good MB, Vichnin MD, 2011. Predictors of HPV vaccine uptake among women aged 19-26: importance of a physician's recommendation. Vaccine 29:890-5.

Sellors JW, Karwalajtys TL, Kaczorowski J, Mahony JB, Lytwyn A, Chong S, Sparrow J, Lorincz A, Survey of HPViOWG, 2003. Incidence, clearance and predictors of human papillomavirus infection in women. CMAJ : Canadian Medical Association journal = journal de l'Association medicale canadienne 168:421-5.

Sirriyeh R, Lawton R, Gardner P, Armitage G, 2012. Reviewing studies with diverse designs: the development and evaluation of a new tool. Journal of evaluation in clinical practice 18:746-52.

Sneller VP, Fishbein DB, Weinbaum CM, Lombard A, Murray P, McLaurin JA, Friedman L, Working Group on Vaccination of High-Risk A, 2008. Vaccinating adolescents in high- 
risk settings: lessons learned from experiences with hepatitis B vaccine. Pediatrics 121 Suppl 1:S55-62.

Watts LA, Joseph N, Wallace M, Rauh-Hain JA, Muzikansky A, Growdon WB, del Carmen MG, 2009. HPV vaccine: A comparison of attitudes and behavioral perspectives between Latino and non-Latino women. Gynecologic oncology 112:577-82.

Zimet GD, Weiss TW, Rosenthal SL, Good MB, Vichnin MD, 2010. Reasons for nonvaccination against HPV and future vaccination intentions among 19-26 year-old women. BMC women's health 10:27. 


\section{Figure Legend}

Figure: PRISMA study flow diagram Abbreviation: (n) number 
Table 1. Characteristics of included studies

\begin{tabular}{|c|c|c|c|c|c|c|c|c|}
\hline $\begin{array}{c}\text { First } \\
\text { author, } \\
\text { year }\end{array}$ & $\begin{array}{l}\text { Study } \\
\text { period }\end{array}$ & $\begin{array}{l}\text { Study } \\
\text { Design }\end{array}$ & Study setting & Sample Size & $\begin{array}{c}\text { Characteristics of } \\
\text { participants }\end{array}$ & $\begin{array}{l}\text { Vaccination } \\
\text { status }\end{array}$ & $\begin{array}{c}\text { Age range } \\
\text { (mean) } \\
\text { in years }\end{array}$ & Funding \\
\hline $\begin{array}{l}\text { Kahn, } \\
2008 \\
\text { (Kahn et } \\
\text { al., 2008) }\end{array}$ & $\begin{array}{l}\text { Oct } 06 \\
\text { - May } \\
07\end{array}$ & QT & $\begin{array}{l}\text { Hospital-based teen } \\
\text { health centre, STD } \\
\text { clinic affiliated with } \\
\text { health department, } \\
\text { obstetrics and } \\
\text { gynaecology clinic } \\
\text { in a community } \\
\text { health centre }\end{array}$ & $\begin{array}{l}418 \text { approached, } \\
409 \text { completed } \\
\text { study }\end{array}$ & $\begin{array}{l}\text { Low income young } \\
\text { women, prior sexual } \\
\text { contact, } 62 \% \text { Black, } 29 \% \\
\text { White, } 18 \% \text { other, } \\
\text { primarily unmarried, } \\
\text { knowledge of HPV (mean } \\
\text { score } 40 \% \text { on a } 12 \text { item } \\
\text { scale), many had history of } \\
\text { STD, abnormal Pap, and } \\
\text { prior pregnancy }\end{array}$ & $\begin{array}{l}\text { Primarily } \\
\text { unvaccinated } \\
(5 \% \text { had at least } \\
1 \text { dose, } 0.2 \% \\
\text { had all } 3 \text { doses) }\end{array}$ & $13-26(18.7)$ & $\begin{array}{l}\text { Charlotte R. } \\
\text { Schmidlapp Women's } \\
\text { Scholar Award }\end{array}$ \\
\hline $\begin{array}{l}\text { Lenehan, } \\
2008 \\
\text { (Lenehan } \\
\text { et al., } \\
2008 \text { ) }\end{array}$ & $\begin{array}{l}\text { Jan - } \\
\text { March } \\
2007\end{array}$ & QT & $\begin{array}{l}\text { Hospital-based, } \\
\text { outpatient obstetrics } \\
\text { and gynaecology } \\
\text { clinic }\end{array}$ & $\begin{array}{l}108 \text { approached, } \\
103 \text { consent, } 98 \\
\text { analyses only } 13 \\
<26 \text { yrs of age }\end{array}$ & Not reported for subgroup & NR & NR & NR \\
\hline $\begin{array}{l}\text { Gerend, } \\
2008 \\
\text { (Gerend } \\
\text { and } \\
\text { Magloire, } \\
\text { 2008) }\end{array}$ & $\begin{array}{l}\text { Feb - } \\
\text { March } \\
2007\end{array}$ & QT & $\begin{array}{l}\text { Campuses of } \\
\text { Florida State } \\
\text { University and } \\
\text { Florida Agricultural } \\
\text { and Mechanical } \\
\text { University }\end{array}$ & $\begin{array}{l}97 \text { ( } 64 \text { were } \\
\text { women, } 60 \text { were } \\
\text { unvaccinated } \\
\text { women) }\end{array}$ & $\begin{array}{l}\text { Most were undergraduate } \\
\text { students, Black (57\%), } \\
\text { White }(32 \%) \text {, all were } \\
\text { single }(2 / 3 \text { dating or in a } \\
\text { committed relationship) }\end{array}$ & $\begin{array}{l}64 \text { women in } \\
\text { study: } 4 \text { were } \\
\text { vaccinated, } \\
60 \text { were } \\
\text { unvaccinated }\end{array}$ & $\begin{array}{l}18-26 \\
(19.03)\end{array}$ & NR \\
\hline $\begin{array}{l}\text { Bynum, } \\
2009 \\
\text { (Bynum et } \\
\text { al., 2009) }\end{array}$ & $\begin{array}{l}\text { Jan- } \\
\text { Apr } \\
2007\end{array}$ & $\mathrm{M}$ & $\begin{array}{l}\text { Teen clinic in } \\
\text { Columbia, South } \\
\text { Carolina (urban) }\end{array}$ & $\begin{array}{l}73 \text { completed } \\
\text { questionnaire, } 68 \\
\text { completed in- } \\
\text { depth interview }\end{array}$ & $\begin{array}{l}\text { Black (80\%), most } \\
\text { insured, most with high } \\
\text { school education, most } \\
\text { sexually active, } 1 / 4 \text { with } \\
\text { past history of STI, } 4 \% \\
\text { reported an HPV diagnosis }\end{array}$ & NR & $14-20(17.9)$ & NR \\
\hline $\begin{array}{l}\text { Allen, } \\
2009 \\
\text { (Allen et } \\
\text { al., 2009) }\end{array}$ & $\begin{array}{l}\text { Feb - } \\
\text { March } \\
2007\end{array}$ & QT & $\begin{array}{l}\text { Private New } \\
\text { England University }\end{array}$ & $\begin{array}{l}1897 \text { consented, } \\
1696 \text { completed } \\
\text { more than } 50 \% \text { of } \\
\text { survey, final } \\
\text { sample } 1401\end{array}$ & $\begin{array}{l}\text { No prior history of } \\
\text { cervical cancer or HPV, } \\
\text { most White (78\%), almost } \\
\text { all had heard of HPV and } \\
\text { the vaccine, almost half } \\
\text { had never had a Pap test, } \\
\text { most had never been } \\
\text { diagnosed with an STI, } \\
\text { almost half were currently } \\
\text { sexually active }\end{array}$ & $\begin{array}{l}1226 \\
\text { unvaccinated } \\
(87 \%) ; 175 \\
(13 \%) \\
\text { vaccinated }\end{array}$ & $18-22(\mathrm{NR})$ & NR \\
\hline
\end{tabular}


ACCEPTED MANUSCRIPT

\begin{tabular}{|c|c|c|c|c|c|c|c|c|}
\hline $\begin{array}{l}\text { Costar, } \\
2008 \\
\text { (Costar, } \\
\text { 2008) }\end{array}$ & $\begin{array}{l}\text { Spring } \\
2007\end{array}$ & $\mathrm{M}$ & $\begin{array}{l}\text { University of } \\
\text { Maryland, } \\
\text { University of } \\
\text { Maine, University } \\
\text { of Massachusetts, } \\
\text { Dartmouth, } \\
\text { University of } \\
\text { Virginia }\end{array}$ & 251 & $\begin{array}{l}75 \% \text { White, two thirds } \\
\text { sexually active, } 94 \% \text { with } \\
\text { health insurance, low to } \\
\text { moderate levels of } \\
\text { knowledge about HPV } \\
\text { (mean score } 3.3 / 7 \text { ) and the } \\
\text { HPV vaccine (mean score } \\
3.02 / 7 \text { ) }\end{array}$ & Unvaccinated & $18-24(19.7)$ & NR \\
\hline $\begin{array}{l}\text { Jain, } 2009 \\
\text { (Jain et al., } \\
\text { 2009) }\end{array}$ & $\begin{array}{l}\text { May - } \\
\text { Aug } \\
2007\end{array}$ & QT & $\begin{array}{l}\text { United States of } \\
\text { America } \\
\text { households }\end{array}$ & $\begin{array}{l}1102 \text { for whole } \\
\text { study; } 168 \text { for } \\
\text { subgroup }\end{array}$ & Not reported for subgroup & $\begin{array}{l}\text { Mostly } \\
\text { unvaccinated } \\
\text { (10\% had } \\
\text { initiated } \\
\text { vaccination) }\end{array}$ & $\begin{array}{l}18-49 \text { for } \\
\text { whole study; } \\
\text { subgroup } \\
18-26\end{array}$ & NR \\
\hline $\begin{array}{l}\text { Read, } \\
2010 \\
\text { (Read et } \\
\text { al., 2010) }\end{array}$ & $\begin{array}{l}\text { Jan } \\
07- \\
\text { June } \\
08\end{array}$ & QT & $\begin{array}{l}\text { Urban, adolescent } \\
\text { medicine clinic }\end{array}$ & 175 & $\begin{array}{l}\text { Black 51\%, Caribbean } \\
39 \%, 76 \% \text { in high school } \\
\text { or less than a high school } \\
\text { education; nearly half } \\
\text { sexually active; most with } \\
\text { more than } 1 \text { prior sexual } \\
\text { partner, } 27 \% \text { reported ever } \\
\text { having an STI, over half } \\
\text { knew what HPV is }\end{array}$ & NR & $\begin{array}{l}13-21(\mathrm{NR}) \\
\text { more than } \\
\text { half were } \\
\text { under } 16\end{array}$ & NR \\
\hline $\begin{array}{l}\text { Conroy, } \\
2009 \\
\text { (Conroy et } \\
\text { al., 2009) }\end{array}$ & $\begin{array}{l}\text { June- } \\
\text { Dec } \\
2007\end{array}$ & QT & $\begin{array}{l}\text { Urban, hospital- } \\
\text { based teen health } \\
\text { centre }\end{array}$ & 189 & $\begin{array}{l}\text { All with prior sexual } \\
\text { contact mostly black } \\
\text { low-income had received } \\
\text { information about HPV } \\
\text { and the vaccine previously } \\
\text { in the baseline study } \\
\text { majority insured most with } \\
\text { history of prior STI }\end{array}$ & $\begin{array}{l}36 \% \text { had } \\
\text { initiated } \\
\text { vaccination; } \\
13 \% \text { had } \\
\text { completed } \\
\text { vaccination; }\end{array}$ & $13-26(17.5)$ & NR \\
\hline $\begin{array}{l}\text { Grant, } \\
2009 \\
\text { (Grant et } \\
\text { al., 2009) }\end{array}$ & 2007 & DR & $\begin{array}{l}\text { California } \\
\text { households }\end{array}$ & NR & NR & Unvaccinated & $18-26$ (NR) & $\begin{array}{l}\text { Many non- } \\
\text { proprietary sources }\end{array}$ \\
\hline $\begin{array}{l}\text { Caskey, } \\
2009 \\
\text { (Caskey et } \\
\text { al., 2009) }\end{array}$ & $\begin{array}{l}\text { Nov } \\
2007\end{array}$ & QT & $\begin{array}{l}\text { United states of } \\
\text { America } \\
\text { households }\end{array}$ & $\begin{array}{l}\text { 2143_total_ } \\
\text { (1011 completed } \\
\text { questionnaire; } \\
412 \text { age } 13-17 \& \\
599 \text { age } 18-26)\end{array}$ & $\begin{array}{l}\text { Approximately half had } \\
\text { less than high school } \\
\text { education (due to age), } \\
\text { mostly White }(17 \%), \\
\text { Hispanic (13\%), Black } \\
\text { average household income } \\
\text { most had heard of HPV } \\
\text { and the vaccine }\end{array}$ & $\begin{array}{l}124(30 \%) \text { of } \\
\text { girls age } 13-17 \\
\text { had initiated } \\
\text { vaccination; } \\
57(9 \%) \text { of girls } \\
\text { age } 8-26 \text { had } \\
\text { initiated } \\
\text { vaccination }\end{array}$ & $13-26(19.4)$ & $\begin{array}{l}\text { Supported in part by } \\
\text { an unrestricted pilot } \\
\text { grant from the } \\
\text { University of } \\
\text { Chicago Program in } \\
\text { Pharmaceutical } \\
\text { Policy funded by the } \\
\text { Merck Foundation }\end{array}$ \\
\hline
\end{tabular}




\begin{tabular}{|c|c|c|c|c|c|c|c|c|}
\hline $\begin{array}{l}\text { Rand, } \\
2011 \\
\text { (Rand et } \\
\text { al., 2011) }\end{array}$ & $\begin{array}{l}\text { Mar } \\
07- \\
\text { Apr } 08\end{array}$ & QT & $\begin{array}{l}5 \text { urban and } 4 \\
\text { suburban primary } \\
\text { care practices in } \\
\text { Monroe County } \\
\text { New York }\end{array}$ & $\begin{array}{l}119 \text { female } \\
\text { adolescents age } \\
15-17 \text { (calculated } \\
\text { based on info } \\
\text { provided in } \\
\text { report); total } \\
\text { sample was } 638 \\
\text { including both } \\
\text { parents and } \\
\text { adolescents }\end{array}$ & $\begin{array}{l}\text { Mostly White; non- } \\
\text { Hispanic; parental income } \\
\text { > } \$ 50000 ; \text { at least some } \\
\text { parental college education; } \\
\text { most had discussed HPV } \\
\text { vaccine with a health care } \\
\text { provider; }\end{array}$ & $\begin{array}{l}65 \% \text { vaccinated } \\
\text { (at least } 1 \text { dose) }\end{array}$ & $\begin{array}{l}15-17 \\
\text { (subgroup of } \\
\text { older } \\
\text { adolescents) }\end{array}$ & $\begin{array}{l}\text { Centers for Disease } \\
\text { Control and } \\
\text { Prevention }\end{array}$ \\
\hline $\begin{array}{l}\text { Mathur, } \\
2010 \\
\text { (Mathur et } \\
\text { al., 2010) }\end{array}$ & $\begin{array}{l}\text { Aug } \\
07-\text { Feb } \\
08\end{array}$ & QT & $\begin{array}{l}\text { Private all-girls } \\
\text { high school and } \\
\text { public co- } \\
\text { educational high } \\
\text { school in San } \\
\text { Francisco }\end{array}$ & $\begin{array}{l}175 \text { (100 at } \\
\text { private school; } 75 \\
\text { at public school) }\end{array}$ & $\begin{array}{l}\text { Grade } 9,10,11 \text {, and } 12 \\
\text { students; Average HPV- } \\
\text { related knowledge; } 48 \% \\
\text { participated in the decision } \\
\text { about receiving } \\
\text { vaccination }\end{array}$ & $\begin{array}{l}37.8 \% \\
\text { vaccinated; } \\
45.5 \% \text { un- } \\
\text { vaccinated; } \\
16.7 \% \text { unsure if } \\
\text { they had been } \\
\text { vaccinated }\end{array}$ & $\begin{array}{l}\text { Range NR; } \\
\text { (16.1 for } \\
\text { vaccinated } \\
\text { girls; } 15.7 \\
\text { for } \\
\text { unvaccinated } \\
\text { girls) }\end{array}$ & NR \\
\hline $\begin{array}{l}\text { Watts, } \\
2009 \\
\text { (Watts et } \\
\text { al., 2009) }\end{array}$ & $\begin{array}{l}\text { Aug } \\
07- \\
\text { Apr } 08\end{array}$ & QT & $\begin{array}{l}\text { General medicine, } \\
\text { gynaecology, or } \\
\text { paediatric units at } \\
\text { the Massachusetts } \\
\text { General Hospital }\end{array}$ & $\begin{array}{l}91 \text { vaccine } \\
\text { eligible } \\
\text { participants age } \\
18-26 \text { yrs } \\
\text { (subgroup) }\end{array}$ & Not reported for subgroup & $\begin{array}{l}44 \% \text { vaccinated } \\
\text { among vaccine } \\
\text { eligible } \\
\text { population }(18- \\
26)\end{array}$ & $\begin{array}{l}\text { NR for } \\
\text { subgroup }\end{array}$ & NR \\
\hline $\begin{array}{l}\text { Moore, } \\
2010 \\
\text { (Moore et } \\
\text { al., 2010) }\end{array}$ & $\begin{array}{l}\text { Oct } \\
07- \\
\text { May } \\
08\end{array}$ & QT & $\begin{array}{l}\text { Waiting area for } \\
\text { gynaecological care } \\
\text { at university health } \\
\text { services at the } \\
\text { University of } \\
\text { Kentucky }\end{array}$ & $\begin{array}{l}235 \text { eligible; } 209 \\
\text { analyzed }\end{array}$ & $\begin{array}{l}\text { Mostly White }(82 \%) \text {, } \\
\text { Black }(12 \%)\end{array}$ & Unvaccinated & $18-24(20.7)$ & $\begin{array}{l}\text { Supported in part by } \\
\text { the William Gallion } \\
\text { Family Foundation } \\
\text { through the } \\
\text { University of } \\
\text { Kentucky's Markey } \\
\text { Cancer Center }\end{array}$ \\
\hline $\begin{array}{l}\text { Licht, } \\
2010 \\
\text { (Licht et } \\
\text { al., 2010) }\end{array}$ & NR & QT & $\begin{array}{l}\text { Two United States } \\
\text { universities in New } \\
\text { York State }\end{array}$ & 406 & $\begin{array}{l}\text { All had previous } \\
\text { knowledge of HPV; } \\
\text { mostly White; some Asian, } \\
\text { African American; }\end{array}$ & $\begin{array}{l}44 \% \\
\text { vaccinated; } \\
56 \% \text { un- } \\
\text { vaccinated }\end{array}$ & $18-26(\mathrm{NR})$ & NR \\
\hline $\begin{array}{l}\text { Zimet, } \\
2010 \\
\text { (Zimet et } \\
\text { al., 2010) }\end{array}$ & $\begin{array}{l}\text { Apr- } \\
\text { May } \\
08\end{array}$ & QT & $\begin{array}{l}\text { United States of } \\
\text { America } \\
\text { households }\end{array}$ & 185 & $\begin{array}{l}80 \% \text { White; } \\
\text { mostly unmarried; } \\
\text { most with good to } \\
\text { excellent health status; } \\
\text { most with at least some } \\
\text { college education; all } \\
\text { insured; } \\
\text { almost all had heard of the } \\
\text { HPV vaccine }\end{array}$ & Unvaccinated & $19-26$ & Merck \& Co \\
\hline
\end{tabular}




\begin{tabular}{|c|c|c|c|c|c|c|c|c|}
\hline $\begin{array}{l}\text { Hopfer, } \\
2011 \\
\text { (Hopfer } \\
\text { and } \\
\text { Clippard, } \\
2011 \text { ) }\end{array}$ & $\begin{array}{l}\text { Apr- } \\
\text { May } \\
08\end{array}$ & $\mathrm{QL}$ & $\begin{array}{l}\text { A large North- } \\
\text { eastern University } \\
\text { in the United States }\end{array}$ & 36 & $\begin{array}{l}90 \% \text { White; almost all } \\
\text { with insurance; } 3 / 4 \text { raised } \\
\text { in suburban } \\
\text { neighbourhoods; all had } \\
\text { heard of the HPV vaccine; } \\
\text { more than half sexually } \\
\text { active; } 81 \% \text { accepting of } \\
\text { vaccination }\end{array}$ & $\begin{array}{l}39 \% \\
\text { vaccinated; } \\
61 \% \text { un- } \\
\text { vaccinated }\end{array}$ & $18-26(20)$ & $\begin{array}{l}\text { Grant support from } \\
\text { the Centers for } \\
\text { Disease Control and } \\
\text { Prevention }\end{array}$ \\
\hline $\begin{array}{l}\text { Rosenthal, } \\
2011 \\
\text { (Rosenthal } \\
\text { et al., } \\
2011 \text { ) }\end{array}$ & $\begin{array}{l}\text { Apr- } \\
\text { May } \\
08\end{array}$ & QT & $\begin{array}{l}\text { United States of } \\
\text { America } \\
\text { households }\end{array}$ & 530 & $\begin{array}{l}80 \% \text { White; mostly } \\
\text { unmarried; most with good } \\
\text { to excellent health status; } \\
\text { most with at least some } \\
\text { college education; all } \\
\text { insured }\end{array}$ & $\begin{array}{l}345 \text { vaccinated } \\
\text { with at least } \\
\text { one dose } \\
(65 \%) ; 185 \\
\text { unvaccinated } \\
(35 \%)\end{array}$ & $\begin{array}{l}19-26(21.2 \\
\text { vaccinated } \\
\text { group }) ; \\
(22.4 \\
\text { unvaccinated } \\
\text { group) }\end{array}$ & $\begin{array}{l}\text { NR } \\
\text { (one author from } \\
\text { Merck) }\end{array}$ \\
\hline $\begin{array}{l}\text { Dillard, } \\
2010 \\
\text { (Dillard } \\
\text { and Spear, } \\
\text { 2011) }\end{array}$ & $\begin{array}{l}\text { Fall } \\
2008\end{array}$ & QT & $\begin{array}{l}\text { Penn State } \\
\text { University }\end{array}$ & 396 & $\begin{array}{l}96 \% \text { had heard of HPV; } \\
98 \% \text { had heard of the } \\
\text { vaccine; } 89 \% \text { White; }\end{array}$ & $\begin{array}{l}53 \% \\
\text { vaccinated; } \\
47 \% \\
\text { unvaccinated }\end{array}$ & $18-24$ & NR \\
\hline $\begin{array}{l}\text { Janousek, } \\
2011 \\
\text { (Janousek, } \\
\text { 2011) }\end{array}$ & $\begin{array}{l}\text { Fall } \\
2009\end{array}$ & QT & $\begin{array}{l}\text { Religiously } \\
\text { conservative } \\
\text { Lutheran university } \\
\text { in Nebraska }\end{array}$ & 203 & $\begin{array}{l}96.6 \% \text { White; } \\
\text { over half not dating; } \\
\text { over half enrolled in a } \\
\text { church work related major; } \\
71 \% \text { had never had vaginal } \\
\text { sexual intercourse; good } \\
\text { knowledge of HPV ( } 80 \% \\
\text { had } \geq 7 / 10 \text { on knowledge } \\
\text { questions) } \\
66 \% \text { not accepting of the } \\
\text { vaccine; } 85 \% \text { with a high } \\
\text { religiosity score }\end{array}$ & $\begin{array}{l}20.7 \% \\
\text { vaccinated; } \\
79.3 \% \\
\text { unvaccinated }\end{array}$ & $18-25(\mathrm{NR})$ & NR \\
\hline $\begin{array}{l}\text { Bendik, } \\
2011 \\
\text { (Bendik et } \\
\text { al., 2011) }\end{array}$ & NR & QT & $\begin{array}{l}\text { Large, South- } \\
\text { eastern United } \\
\text { States university }\end{array}$ & 1975 & $\begin{array}{l}90 \% \text { White; } 95 \% \text { had } \\
\text { heard of HPV; } 2 / 3 \text { never } \\
\text { sexually active; mean } \\
\text { HPV knowledge score was } \\
6.85 / 10\end{array}$ & $\begin{array}{l}37.7 \% \\
\text { vaccinated with } \\
\text { at least one } \\
\text { dose; } 62.3 \% \\
\text { unvaccinated }\end{array}$ & $18-23(20)$ & $\begin{array}{l}\text { Clemson University } \\
\text { Calhoun Honours } \\
\text { College Departmental } \\
\text { Honours Grant and } \\
\text { the Clemson } \\
\text { University } \\
\text { Department of Public } \\
\text { Health Sciences } \\
\text { Mary Lohr Fund }\end{array}$ \\
\hline
\end{tabular}

Abbreviations: QT quantitative, QL qualitative, M mixed, DR data report, STD sexually transmitted disease, STI sexually transmitted infection, HPV human papillomavirus, NR not reported. 
Table 2. Self-reported barriers and facilitators to preventive HPV vaccination among adolescent girls and young women reported in studies in systematic review

\begin{tabular}{|c|c|}
\hline First author, year & Supporting information \\
\hline \multicolumn{2}{|c|}{ Facilitators (\% participants who mentioned each facilitator or rank order) } \\
\hline $\begin{array}{l}\text { Lenehan, } 2008 \\
\text { (Lenehan et al., 2008) }\end{array}$ & Ordered from most to least influential factor: doctor recommendation, no cost, 5 year efficacy, the need for 3 injections \\
\hline $\begin{array}{l}\text { Jain, } 2009 \text { (Jain et al., } \\
\text { 2009) }\end{array}$ & Provider recommendation $90 \%$ (of the 49 females who were not aware of the vaccine) \\
\hline $\begin{array}{l}\text { Caskey, } 2009 \\
\text { (Caskey et al., 2009) }\end{array}$ & $\begin{array}{l}\text { Among unvaccinated participants: } \\
\text { For total population: health provider recommendation }(83 \%) \text {; parent recommendation }(82 \%) \text {; cost covered }(74 \%) \text {; if had past abnormal Pap } \\
\text { test }(79 \%) \text {; many close friends getting it }(55 \%) \text {; } \\
\text { For age } 13-17 \text { years: parent recommendation }(89 \%) \text {; health provider recommendation } 78 \%) \text {; past abnormal Pap test }(78 \%) \text {; cost covered } \\
(68 \%) \text {; many close friends getting it }(52 \%)\end{array}$ \\
\hline $\begin{array}{l}\text { Rand, } 2011 \text { (Rand et } \\
\text { al., 2011) }\end{array}$ & Among those vaccinated: doctor recommended it; preventing a serious and common disease (proportions NR) \\
\hline $\begin{array}{l}\text { Watts, 2009 (Watts et } \\
\text { al., 2009) }\end{array}$ & Anti-cancer benefit $81 \%$; anti-warts benefit $3 \%$ \\
\hline $\begin{array}{l}\text { Bendik, } 2011 \text { (Bendik } \\
\text { et al., 2011) }\end{array}$ & $\begin{array}{l}\text { Among those unvaccinated (what would motivate them most to receive the vaccine): doctor advises getting vaccinated (35.4\%); a way to pay } \\
\text { for the vaccine }(19.5 \%) \text {; parental endorsement }(16.4 \%) \text {; becoming sexually active }(14 \%) \text {; start having sex with more partners }(9.6 \%)\end{array}$ \\
\hline \multicolumn{2}{|c|}{ Barriers (\% participants who mentioned each barrier or rank order) } \\
\hline $\begin{array}{l}\text { Lenehan, } 2008 \\
\text { (Lenehan et al., 2008) }\end{array}$ & Cost became more of a barrier as the hypothetical cost of vaccination increased \\
\hline $\begin{array}{l}\text { Bynum, } 2009 \\
\text { (Bynum et al., 2009) }\end{array}$ & $\begin{array}{l}\text { Cost } 34 \% \text {; lack of transportation } 22 \% \text {; fear of vaccines } 19 \% \text {; social norms } 19 \% \text {; subjective norms } 14 \% \text {; feeling unable to talk to parent or } \\
\text { caregiver } 11 \% \text {; fear of needles } 9 \% \text {; do not think it will work } 4 \% \text {; need for } 3 \text { doses } 3 \%\end{array}$ \\
\hline $\begin{array}{l}\text { Jain, } 2009 \text { (Jain et al., } \\
\text { 2009) }\end{array}$ & $\begin{array}{l}\text { No need because not sexually active } 28 \% \text {; not time to make an appointment } 21 \% \text {; no need because healthy or not at risk } 20 \% \text {; vaccine too } \\
\text { new or might have side effects } 11 \% \text {; costs and insurance issues } 7 \% \text {; fear of needles } 6 \% \text {; already exposed to HPV } 6 \% \text {; not aware of HPV or } \\
\text { the vaccine } 2 \%\end{array}$ \\
\hline $\begin{array}{l}\text { Read, } 2010(\text { Read et } \\
\text { al., 2010) }\end{array}$ & $\begin{array}{l}\text { Do not know enough about the vaccine because the vaccine is too new }(40 \%) \text {; belief that they were too young to think about or have sex } \\
(31.4 \%)\end{array}$ \\
\hline $\begin{array}{l}\text { Conroy, } 2009 \\
\text { (Conroy et al., 2009) }\end{array}$ & $\begin{array}{l}\text { Among those who refused vaccination: concern about insurance coverage } 13 / 15(86.7 \%) \text {; } \\
\text { Among unvaccinated: not returned to the clinic since the baseline visit } 45 \% \text {;returned to the clinic but not offered the vaccine } 42 \% \text {; concerns } \\
\text { about safety and efficacy }\end{array}$ \\
\hline $\begin{array}{l}\text { Grant, 2009 (Grant et } \\
\text { al., 2009) }\end{array}$ & Do not know enough about the vaccine $(31 \%)$, worried about safety $(7 \%)$, do not need the vaccine $(19 \%)$, other $(37 \%)$ \\
\hline $\begin{array}{l}\text { Caskey, } 2009 \\
\text { (Caskey et al., 2009) }\end{array}$ & $\begin{array}{l}\text { For total population: not sexually active }(29 \%) \text {; concerns about vaccine safety }(27 \%) \text {; cost }(16 \%) \text {; unsure if vaccine works }(14 \%) \text {; doctor } \\
\text { doesn't think vaccine needed }(5 \%) \text {; other (e.g. pregnant, married, already have HPV) }(9 \%) \\
\text { For age } 13-17 \text { years: not sexually active }(47 \%) \text {; safety concerns }(26 \%) \text {; unsure if vaccine works }(16 \%) \text {; other }(13 \%) \text {; cost }(10 \%) \text {; vaccine not } \\
\text { available }(2 \%) \text {; doctor doesn't think it's needed }(1 \%)\end{array}$ \\
\hline $\begin{array}{l}\text { Rand, } 2011 \text { (Rand et } \\
\text { al., 2011) }\end{array}$ & $\begin{array}{l}\text { Among those who refused vaccination: not at risk (36\%); perception that vaccine had not been studied enough (21\%); not wanting to receive } \\
\text { a shot }(11 \%) \text {; want to do more research to make an informed decision }(5 \%)\end{array}$ \\
\hline $\begin{array}{l}\text { Mathur, } 2010 \\
\text { (Mathur et al., 2010) }\end{array}$ & Don't consider the vaccine safe $(25 \%$ among those who participated in the decision; $8.5 \%$ among unvaccinated girls \\
\hline $\begin{array}{l}\text { Watts, } 2009 \text { (Watts et } \\
\text { al., 2009) }\end{array}$ & Cost $(46 \%)$ \\
\hline Zimet, 2010 (Zimet et & $(51.1 \%)$, \\
\hline
\end{tabular}




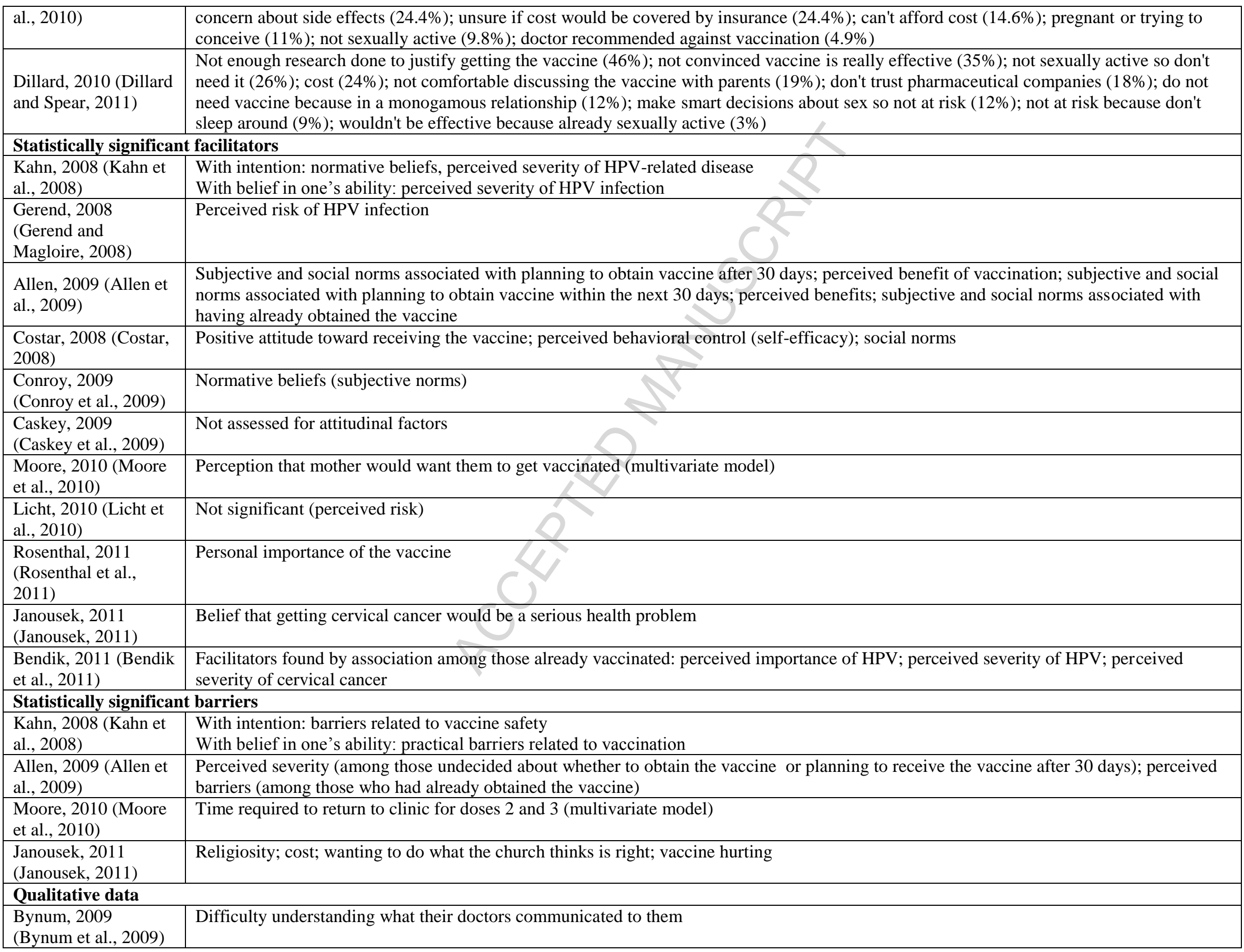


Costar, 2008 (Costar, 2008)

Hopfer, 2011 (Hopfe and Clippard, 2011)
Facilitators: benefits of prevention; benefits of reducing worry; perceiving self at risk; attitude toward vaccination; social norms; Barriers: pros do not outweigh cons ; increased anxiety (fear of needles, side effects); don't perceive self at risk; negative attitudes toward vaccination; social norms; perceived behavioural control (self-efficacy)

Facilitators (acceptance): supportive family messages; explicit health care provider endorsement; peer descriptive norms reducing stigma of vaccination; disease framing (cancer) shaping vaccine benefit perceptions.

Barriers (resistance): scepticism of vaccine safety, invoking alternative prevention strategies (e.g. safe and un-risky sexual behaviour); articulating stigmatizing HPV messages; overcoming self-efficacy barriers (cost, availability, time, fear of parental disclosure); delay strategies (for all women relationship status framed perception of susceptibility to HPV) 
Table 3. Self-reported barriers and facilitators to preventive HPV vaccination among 9-26 year old females

\begin{tabular}{|c|c|c|c|c|}
\hline & $\begin{array}{c}\text { Identified as } \\
\text { statistically } \\
\text { significant in a } \\
\text { quantitative study } \\
\text { (\# of studies) }\end{array}$ & $\begin{array}{c}\text { Identified in a } \\
\text { quantitative study } \\
\text { as a proportion or } \\
\text { other result } \\
\text { (\# of studies) } \\
\end{array}$ & $\begin{array}{c}\text { Identified in a } \\
\text { qualitative study } \\
\text { (\# of studies) }\end{array}$ & $\begin{array}{c}\text { Total } \\
\text { number of } \\
\text { studies in } \\
\text { which } \\
\text { identified } \\
\end{array}$ \\
\hline \multicolumn{5}{|c|}{ Barriers to preventive HPV vaccination identified among studies } \\
\hline Cost & $\checkmark \quad(1)$ & $\begin{array}{ll} \\
\checkmark & (8)\end{array}$ & $\sqrt{ } \quad(1)$ & 10 \\
\hline $\begin{array}{l}\text { Don't need it (e.g. perceived risk, } \\
\text { perceived severity, in a relationship) }\end{array}$ & $\checkmark$ (1) & $\checkmark \quad(6)$ & $\checkmark$ (2) & 9 \\
\hline Concerns about safety and side effects & $\checkmark \quad(1)$ & $\sqrt{ }(6)$ & $\checkmark \quad(2)$ & 9 \\
\hline $\begin{array}{l}\text { Practical barriers (e.g. requires } 3 \text { doses, } \\
\text { booking an appointment, transportation) }\end{array}$ & $\checkmark(2)$ & $\checkmark(4)$ & $\checkmark \quad(1)$ & 7 \\
\hline Fear of needles & $\checkmark(1)$ & $\checkmark(3)$ & $\checkmark \quad(1)$ & 5 \\
\hline Too new & & $\sqrt{ }(5)$ & & 5 \\
\hline Not sexually active & & $\sqrt{ }(5)$ & & 5 \\
\hline $\begin{array}{l}\text { Doctor related (doesn't think it's needed, } \\
\text { recommended against it, didn't mention it, } \\
\text { difficulty understanding what was } \\
\text { communicated) }\end{array}$ & & & $\checkmark(1)$ & 4 \\
\hline Efficacy concerns & & $\checkmark \quad(4)$ & & 4 \\
\hline Social norms & & $\checkmark \quad(1)$ & $\checkmark \quad(2)$ & 3 \\
\hline $\begin{array}{l}\text { Unable to talk to parents about it (e.g. } \\
\text { uncomfortable, fear of disclosure) }\end{array}$ & & $\checkmark(2)$ & $\checkmark$ (1) & 3 \\
\hline $\begin{array}{l}\text { Want more information (e.g. to make an } \\
\text { informed decision) }\end{array}$ & & $\checkmark(3)$ & & 3 \\
\hline $\begin{array}{l}\text { No benefit (e.g. already exposed to HPV, } \\
\text { sexually active) }\end{array}$ & & $\checkmark \quad(3)$ & & 3 \\
\hline Anti-vaccination views & & $\checkmark \quad(1)$ & $\checkmark \quad(1)$ & 2 \\
\hline Subjective norms & $\checkmark(1)$ & $\checkmark \quad(1)$ & & 2 \\
\hline Pregnant or trying to conceive & 8 & $\checkmark \quad(2)$ & & 2 \\
\hline Self-efficacy & P & & $\checkmark(2)$ & 2 \\
\hline $\begin{array}{l}\text { Pros do not outweigh cons or general } \\
\text { feelings of barriers }\end{array}$ & $\checkmark(1)$ & & $\checkmark(1)$ & 2 \\
\hline Unaware of HPV or the vaccine & & $\checkmark(1)$ & & 1 \\
\hline Mistrust of pharmaceutical companies & & $\sqrt{ }(1)$ & & 1 \\
\hline $\begin{array}{l}\text { Alternative strategies available (safe and } \\
\text { un-risky sexual behaviour) }\end{array}$ & & & $\checkmark(1)$ & 1 \\
\hline \multicolumn{5}{|c|}{ Facilitators to preventive HPV vaccination identified among studies } \\
\hline Perceived benefit & $\checkmark(2)$ & $\checkmark(2)$ & $\checkmark(2)$ & 6 \\
\hline Health care provider recommendation & & $\checkmark(5)$ & $\checkmark(1)$ & 6 \\
\hline Social norms & $\checkmark(2)$ & $\checkmark(1)$ & $\checkmark(2)$ & 5 \\
\hline Parental endorsement & $\checkmark(1)$ & $\checkmark(2)$ & $\checkmark(1)$ & 4 \\
\hline Perceived risk & $\checkmark(1)$ & $\checkmark(2)$ & $\checkmark \quad(1)$ & 4 \\
\hline Cost-free & & $\checkmark \quad(3)$ & & 3 \\
\hline Subjective norms & $\checkmark \quad(3)$ & & & 3 \\
\hline Perceived severity & $\checkmark \quad(3)$ & & & 3 \\
\hline $\begin{array}{l}\text { Positive attitude toward the vaccine or } \\
\text { personal importance of the vaccine }\end{array}$ & $\checkmark \quad(2)$ & & $\checkmark \quad(1)$ & 3 \\
\hline Self-efficacy & $\checkmark \quad(1)$ & & & 1 \\
\hline Vaccine efficacy (for at least 5 years) & & $\checkmark \quad(1)$ & & 1 \\
\hline
\end{tabular}

Note: $\checkmark$ significant 
Table 4. Self-reported barriers and facilitators to preventive HPV vaccination among adolescent girls < 18 years of age

\begin{tabular}{|c|c|}
\hline $\begin{array}{c}\text { Based upon data from } 3 \text { studies and a total sample } \\
\text { of } 706 \text { adolescent girls }\end{array}$ & $\begin{array}{l}\text { Identified in a quantitative study as a proportion or other result } \\
\text { (proportion of adolescent girls who reported each barrier or facilitator) }\end{array}$ \\
\hline $\begin{array}{l}\text { Barriers to preventive HPV vaccination identified } \\
\text { among studies }\end{array}$ & $\begin{array}{l}\text { Total } 3 \text { studies: } \text { Caskey } 2009^{97} \text { among those who considered vaccination but } \\
\text { declined } \\
\qquad \begin{array}{l}\text { Rand } 2011^{98} \text { among those who refused vaccination } \\
\text { Mathur } 2010^{18} \text { among those who participated in the } \\
\text { decision (to not be vaccinated) }\end{array}\end{array}$ \\
\hline Not sexually active & $\begin{array}{ll}\checkmark \quad 47 \% \text { (Caskey) } \\
\end{array}$ \\
\hline Not at risk & $\checkmark \quad 36 \%$ (Rand) \\
\hline Concerns about vaccine safety & $\begin{array}{l}\checkmark 26 \% \text { (Caskey) } \\
25 \% \text { (Mathur) (8.5\% among unvaccinated girls - whether } \\
\text { they participated in } \\
\quad \text { the decision or not) }\end{array}$ \\
\hline Too new (not studied enough) & $\checkmark 21 \%$ (Rand) \\
\hline Concern about efficacy (not sure if vaccine works) & $\checkmark \quad 16 \%$ (Caskey) \\
\hline Not wanting to receive a shot & $\checkmark 11 \%$ (Rand) \\
\hline Cost & $\checkmark \quad 10 \%$ (Caskey) \\
\hline $\begin{array}{l}\text { Wanting to do more research to make an informed } \\
\text { decision }\end{array}$ & $\checkmark 5 \%$ (Rand) \\
\hline Vaccine not available & $\checkmark 2 \%$ (Caskey) \\
\hline Doctor doesn't think it's needed & $\checkmark \quad 1 \%$ (Caskey) \\
\hline $\begin{array}{l}\text { Facilitators to preventive HPV vaccination } \\
\text { identified among studies }\end{array}$ & 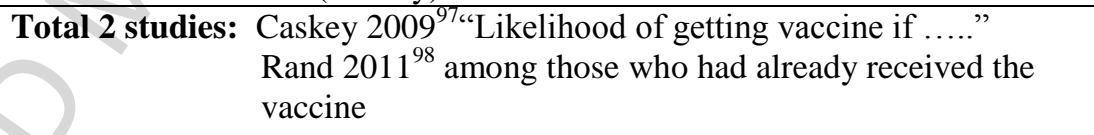 \\
\hline Parent recommendation & $\checkmark 89 \%$ (Caskey) \\
\hline Health provider recommendation & $\begin{array}{ll}\checkmark & 78 \%(\text { Caskey) } \\
\checkmark & \text { NR (Rand) } \\
\end{array}$ \\
\hline Past abnormal Pap test & $\checkmark 78 \%$ (Caskey) \\
\hline Cost covered & $\checkmark 68 \%$ (Caskey) \\
\hline Many close friends getting it & $\checkmark 52 \%$ (Caskey) \\
\hline Preventing a serious and common disease & $\checkmark$ NR (Rand) \\
\hline
\end{tabular}

Note: $\mathrm{NR}=$ not reported 
Table 5. Quality assessment using the tool developed by Sirriyeh et al for diverse study designs ${ }^{86}$ (combined reviewer scores)

\begin{tabular}{|l|c|c|c|c|c|c|c|c|c|c|c|c|c|c|c|c|c|}
\hline \multicolumn{1}{|c|}{ Author, year } & $\mathbf{1}$ & $\mathbf{2}$ & $\mathbf{3}$ & $\mathbf{4}$ & $\mathbf{5}$ & $\mathbf{6}$ & $\mathbf{7}$ & $\mathbf{8}$ & $\mathbf{9}$ & $\mathbf{1 0}$ & $\mathbf{1 1}$ & $\mathbf{1 2}$ & $\mathbf{1 3}$ & $\mathbf{1 4}$ & $\mathbf{1 5}$ & $\mathbf{1 6}$ & $\begin{array}{c}\text { Total score } \\
\text { for study }\end{array}$ \\
\hline Kahn, 2008 & 3 & 3 & 2 & 0 & 2 & 3 & 2 & 0 & 2 & 2 & n/a & 2 & 2 & n/a & 0 & 3 & $\mathbf{2 6}$ \\
\hline Lenehan, 2008 & 0 & 3 & 3 & 0 & 1 & 2 & 2 & 1 & 1 & 1 & n/a & 0 & 1 & n/a & 0 & 1 & $\mathbf{1 6}$ \\
\hline Gerend, 2008 & 0 & 2 & 3 & 0 & 1 & 3 & 2 & 0 & 0 & 1 & n/a & 2 & 2 & n/a & 0 & 3 & $\mathbf{1 9}$ \\
\hline Bynum, 2009 & 0 & 2 & 3 & 0 & 1 & 3 & 2 & 0 & 1 & 2 & 2 & 2 & 1 & 2 & 1 & 3 & $\mathbf{2 5}$ \\
\hline Allen, 2009 & 3 & 3 & 2 & 2 & 2 & 3 & 2 & 2 & 2 & 3 & n/a & 2 & 2 & n/a & 3 & 3 & $\mathbf{3 4}$ \\
\hline Costar, 2008 & 3 & 3 & 3 & 2 & 2 & 3 & 2 & 2 & 2 & 2 & 2 & 0 & 1 & 2 & 2 & 3 & $\mathbf{3 4}$ \\
\hline Jain, 2009 & 0 & 3 & 2 & 2 & 2 & 3 & 0 & 2 & 1 & 2 & n/a & 2 & 2 & n/a & 3 & 2 & $\mathbf{2 6}$ \\
\hline Read, 2010 & 0 & 2 & 1 & 0 & 1 & 1 & 0 & 1 & 1 & 2 & n/a & 2 & 0 & n/a & 0 & 2 & $\mathbf{1 3}$ \\
\hline Conroy, 2009 & 0 & 3 & 3 & 0 & 2 & 3 & 0 & 2 & 2 & 2 & n/a & 2 & 0 & n/a & 0 & 2 & $\mathbf{2 1}$ \\
\hline Caskey, 2009 & 0 & 3 & 3 & 0 & 2 & 3 & 2 & 1 & 0 & 2 & n/a & 2 & 2 & n/a & 0 & 2 & $\mathbf{2 2}$ \\
\hline Rand, 2011 & 2 & 2 & 2 & 2 & 2 & 2 & 2 & 2 & 2 & 2 & n/a & 2 & 2 & n/a & 2 & 1 & $\mathbf{2 7}$ \\
\hline Mathur, 2010 & 0 & 3 & 3 & 0 & 1 & 3 & 1 & 2 & 2 & 2 & n/a & 2 & 1 & n/a & 2 & 2 & $\mathbf{2 4}$ \\
\hline Watts, 2009 & 0 & 2 & 3 & 3 & 2 & 3 & 2 & 2 & 2 & 2 & n/a & 2 & 2 & n/a & 2 & 0 & $\mathbf{2 7}$ \\
\hline Moore, 2010 & 0 & 2 & 3 & 0 & 1 & 2 & 2 & 2 & 0 & 1 & n/a & 2 & 2 & n/a & 0 & 1 & $\mathbf{1 8}$ \\
\hline Licht, 2010 & 0 & 2 & 2 & 0 & 2 & 2 & 0 & 2 & 0 & 2 & n/a & 1 & 2 & n/a & 0 & 1 & $\mathbf{1 6}$ \\
\hline Zimet, 2010 & 0 & 2 & 2 & 2 & 1 & 2 & 0 & 2 & 0 & 2 & n/a & 2 & 1 & n/a & 0 & 2 & $\mathbf{1 8}$ \\
\hline Hopfer, 2011 & 3 & 3 & 3 & 0 & 1 & 3 & 2 & 2 & n/a & n/a & 3 & 3 & 2 & 2 & 1 & 2 & $\mathbf{3 0}$ \\
\hline Rosenthal, 2011 & 0 & 2 & 2 & 0 & 2 & 2 & 2 & 2 & 0 & 1 & n/a & 2 & 0 & n/a & 0 & 2 & $\mathbf{1 7}$ \\
\hline Dillard, 2010 & 0 & 3 & 2 & 0 & 1 & 2 & 1 & 2 & 1 & 1 & n/a & 2 & 1 & n/a & 2 & 2 & $\mathbf{2 0}$ \\
\hline Janousek, 2011 & 3 & 3 & 3 & 3 & 2 & 3 & 2 & 3 & 1 & 1 & n/a & 3 & 1 & n/a & 0 & 1 & $\mathbf{2 9}$ \\
\hline Bendik, 2011 & 1 & 2 & 2 & 0 & 2 & 1 & 1 & 1 & 0 & 1 & n/a & 2 & 1 & n/a & 0 & 1 & $\mathbf{1 5}$ \\
\hline
\end{tabular}

QT = quantitative $\mathrm{QL}=$ qualitative $\mathrm{M}=$ mixed methods

Criteria (scoring items as $0=$ not at all, $1=$ very slightly, $2=$ =moderately, $3=$ complete)

$1=$ explicit theoretical framework

$2=$ statement of aims/objectives in main body of report

$3=$ clear description of research setting

$4=$ evidence of sample size considered in terms of analysis

$5=$ representative sample of target group of a reasonable size

$6=$ description of procedure for data collection

$7=$ rationale for choice of data collection tool(s)

$8=$ detailed recruitment data

$9=$ statistical assessment of reliability and validity of measurement tool(s) (quantitative only)

$10=$ fit between stated research question and method of data collection (quantitative)

$11=$ fit between stated research question and format and content of data collection tool (e.g. interview schedule) (qualitative)

$12=$ fit between research question and method of analysis

$13=$ good justification for analytical method selected

$14=$ assessment of reliability of analytical process (qualitative only)

$15=$ evidence of user involvement in design

$16=$ strengths and limitations critically discussed 


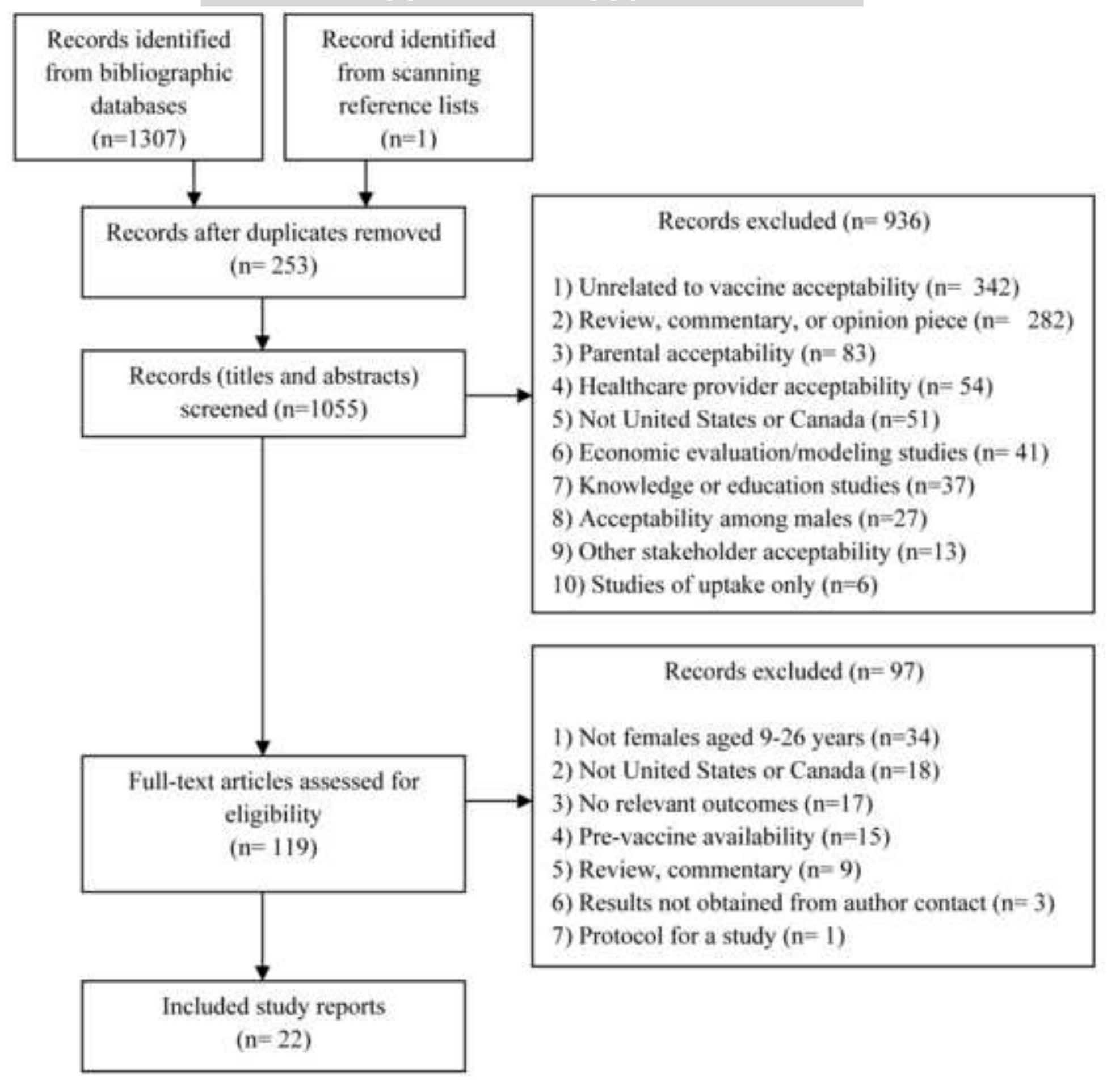

Figure $\square$ 
Highlights

- We examine self-reported views of intended young female HPV vaccine recipients

- When cost is a factor in vaccine access it dominates as a barrier to vaccination

- Perception of risk for HPV health consequences may improve vaccine acceptance

- Importance of influential others is apparent but communication must be effective

- Qualitative, high quality studies among adolescents as a unique group are needed 